\title{
Space, Rurality and Power in Spain: The Agrarian Ideology of Vizconde Eza (1873-1945)
}

\author{
By Angel Paniagua*
}

Eza's agrarian ideology presents multiple dimensions that have not been analyzed systematically until the present day. The approach to Eza has been more punctual or episodic, from a partial or sectarian point of view, without a global consideration of this personage with notable human and social values, recognized for his own labors and employees. Eza provides for posteriori an academic work that offers the opportunity to study a historical period of change in Spanish agriculture, with little attraction among academics for the traditional interest in the study of the II Republic. The agrarian ideology of Eza suggests some relevant elements of interest for the agrarian historiography in the post Franco period, like the regional adaptation of agrarian structures, particularly the latifundios, the relationship between the (rural) individual and the State or the relevance of the micro social agrarian research.

\section{Introduction}

The Viscount of Eza is a polyhedral figure like many agrarian ideologists of the time. However, his agrarian ideology is only part of his intellectual legacy ${ }^{1}$, which also includes aspects of an economic, social and legal nature. His agrarian work has a remarkable temporal trajectory and is, consequently, influenced by the successive historical, national and international avatars. In a historical stage, the Restoration, agrarian social policy had an important rhetoric and little truly practical action ${ }^{2}$, in contrast to the action of agrarian reform in the Second Republic.

Eza identified with the farmer: 'when I am older, I will be a farmer, for everyone's good, starting with myself, I will return to my agricultural school and I will continue to be exactly the same as I am today' ${ }^{13}$ The agrarian Eza, combined the facets of theorist and peasant, to present personal rustic properties in both Cordoba and Soria ${ }^{4}$. This enabled him to be both a man of the country and the city at the same time, which reverberated in many of his judgments and analyses. He conducted studies of agrarian economy, when experimenting on forms of colonization and transport on his own properties, and even on

\footnotetext{
"Senior Scientific Research, Spanish Council for Scientific Research. CSIC, Spain. $27-40$.

1. F. Campo, "El vizconde de Eza y la cooperación," Estudios Cooperativos, 16 (1968):

2. E. Malefakis, Reforma agraria y revolución campesina en la España del siglo XX (Barcelona: Ariel, 1982).

3. E. de Vizconde, La tahona reguladora (Madrid: Sucesora de M. Minuesa de los Rios, 1914), 24.

4. L. Martín Granizo, "Prologo", Antología de las obras del Excmo. Señor Vizconde de Eza (Madrid: Escuela Social de Madrid, 1948).
} 
geographical units and complete towns ${ }^{5}$. In this facet of agrarian ideology, its social preoccupations had remarkable repercussions. This is the main feature that distinguishes Eza from the social Catholics of the time ${ }^{6}$. He held important posts throughout his intense life, he was Director General of Agriculture (1907), coinciding with the start of the policy of agricultural colonies and internal repopulation. He was also a member of the Internal Colonization Board and president of the Social Reforms Institute. Later, he was mayor of Madrid between 1913 and 1914 ${ }^{7}$, Minister of Development in 1917 and the Minister of War between 1920 and 1921, and, finally, deputy to Congress for the constituency of Soria between 1899 and 1923, for the Conservative Party ${ }^{8}$. He was also founding president of the National Association of Farmers and presided the Spanish Association for the Progress of Sciences until his death.

Eza is an interesting figure in catholic-social agrarian thinking of the first third of the 20th century. Of a religious-ideological orientation, which had its origins in the encyclical Renun Novarum of 1891 of Papa Leon XIII, a text that on the one hand preserved the right to individual property ${ }^{9}$, located in a social context ${ }^{10}$ and on the other, aimed at promoting an understanding between the classes. Its content was not only social but also territorial, based on the essence of traditional (rural) life. These two characteristics are both present in the work of Eza, although with clear nuances. Social Catholicism was a heterogeneous movement, in its social and territorial principles. However, its main guidelines also show certain uniformity, which is more or less maintained during the first third of the twentieth century. Eza himself, who could be considered to be of heterodox views within social Catholicism for his attention to and concern for social problems, throughout his life also defended the basic principles of individual property, the capacity of the individual, the moral idealization of rural life and the agrarian family.

Despite the continuity of Eza's agrarian ideology in the first third of the 20th century and its theoretical relevance to the development of agrarian policies, there is no systematic interpretation of this author, who is obscured and overshadowed by the greater attention paid to the reforming thinkers of this historical stage ${ }^{11}$. With this paper, we aim to provide a more global interpretation of Eza's agrarian ideology, and also to review the interpretation 14.

5. P. Sangro, El Vizconde de Eza, gran señor social (Madrid: Ministerio de Trabajo, 1947),

6. J.M. Cuenca Toribio, Catolicismo social y político en la España contemporánea (18702000) (Madrid: Unión Editorial, 2003).

7. A. Calama, "El Vizconde de Eza Don Luis Marichalar y Monreal (1873-1945). Político e intelectual, diputado a Cortes por Soria de 1899 a 1923, Alcalde de Madrid (1913-1914)," Torre de los Lujanes. Boletín de la Real Sociedad Económica Matritense de Amigos del País, 61 (2007): 71-115.

8. Cuenca Toribio, Catolicismo social y político en la España contemporánea, 2003.

9. A. Salcedo Ruiz, El socialismo del campo (Madrid: Imp. de los Huérfanos, 1894); E., Majuelo, and A. Pascual, Del catolicismo agrario al cooperativismo empresarial. Setenta y cinco años de la Federación de Cooperativas navarras, 1910-1985 (Madrid: MAPA, 1991).

10. S. Martínez González, La crisis de la agricultura. Sus causas y sus remedios (Salamanca: Imprenta Católica Salmanticense, 1893).

11. E. Sevilla Guzmán, "Sobre el pensamiento social agrario en España," In Introducción a la sociología rural, ed. H. Newby, and E. Sevilla Guzmán (Madrid: Alianza Ed., 1983). 
of some established geographical and historiographical tendencies relating to the historical period in which he lived.

\section{The Spatial Dimension of the Agrarian Question}

The central aspect of Eza's ideology is the regionalization of agrarian policy and the spatial dimension of the agrarian question. To pursue his ideas, it was necessary to steadily develop a body of knowledge about the physical and socio-economic conditions of each of the regions of the national territory, which could form the basis of a global synthesis ${ }^{12}$. The agronomic physiography that characterizes each region is based on the property and a convenient cultivation system, associated with physical and edaphic factors.

The agricultural structure of Spain was conditioned by the poverty of the land and the inadequate proportions of uncultivated and cultivated land. In the first third of the century, uncultivated land exceeded $60 \%$ of the entire national agricultural area and this constituted an important problem with multiple vertices for agrarian policies of the time. Agriculture was also affected by the remarkable subdivision and small size of the ownership structure, the lack of capital and power and the social isolation of the farmer ${ }^{13}$. The transformation of rural Spain was aimed at achieving a spatial balance between land dedicated to irrigation, mountains and dry land ${ }^{14}$. An adequate balance could be achieved by increasing the cultivated area by 3 million hectares, through the constitution of colonization societies, to reach a total of 28 million hectares. This would entail a small increase in reforestation and dedication of 17 million hectares to crops of dry land, leaving poorer land uncultivated.

Determination of the most favorable cultivation regime for each region will affect the most appropriate type of property that this supports (large, small and medium). The social function of property has a double meaning in Eza's thinking: (1) to obtain from each land the maximum profitability by adapting it to the kind of exploitation or cultivation that is appropriate, -the agricultural operation is that which produces material that the land needs for its growth in order to obtain benefits from the capital and labor invested ${ }^{15}$; (2) to enable as many families as possible to settle on these lands. Eza's agrarian program aimed to double agricultural production and also the Spanish population. These opinions were shared by other agrarian ideologists of social Catholicism and reformist inspiration of the period, like Molins ${ }^{16}$. It suggests that in order for agriculture to develop, an agricultural population constituted by agrarian families is required.

12. E. de Vizconde, Conservación y creación de las pequeñas explotaciones agrícolas (Madrid: Bernardo Rodríguez, 1911), 22.

13. E. de Vizconde, El riesgo profesional en la agricultura (Madrid: Suc. M. Minuesa de los Ríos, 1906).

14. E. de Vizconde, El solar español: su fuerza social, económica y tributaria (Madrid: Ruiz hermanos, 1926).

15. E. de Vizconde, El riesgo profesional en la agricultura (Madrid: Suc. M. Minuesa de los Ríos, 1906).

16. J.E. Molins, La crisis en España (Barcelona: Imp. Barcelonesa,1904). 
Complementary to the agro-physical study, in Eza's ideology it is also essential to carry out a social study, based on the conditions of the population and individual initiatives ${ }^{17}$, the land they develop and their regional social function. In some cases, small farmers in the countryside or workers in the city must become small landowners; in others, however, it is necessary to expand or to introduce suitable conditions to cultivate plots or lots disintegrated today ${ }^{18}$. This concern for management of the agricultural area, an adequate distribution of the arable land, together with the need to repopulate the countryside, all had a notable influence on the first political regime of Franco ${ }^{19}$.

The problem of 'latifundismo' is linked mainly to two regions: Andalusia and Extremadura, due to the historical process of the reconquest ${ }^{20}$. Eza participates in the southern vision of the agrarian question in Spain, as recognized by an orientation of agrarian history ${ }^{21}$. However, the large size of the property would not be a problem in itself for Eza but rather the poor exploitation of large farms. Their subdivision into lots is not viable in economic terms and does not permit management beyond $10 \%$ of the farm area. This is the main point of divergence from the agrarian reformists of the time. In other areas of Spain the problem lay in the dispersion of the property. The politics of the State in some areas entailed subdivision and in others areas concentration, through a policy of incentives to individual initiative. The State can only intervene in the organization of property -say the social Catholics- when it does not respond to social purposes and harms public welfare ${ }^{22}$.

The problem was not the size of the property but achieving a management appropriate to the conditions of the physical environment. Here, Eza participates in a debate that was to some extent common among the agrarian ideologists of his time (of different ideologies): the limits of the physical environment and the great agrarian property ${ }^{23}$. In any case, the social problem in rural areas is real, as Eza suggests, as the complaints of the rural workers show. This social vision of the rural problem is a characteristic of Eza's ideology, and accompanies him throughout his life, distinguishing him from conservative and catholic social agrarian thinking of the time.

The social facet of the agrarian question is shown in the direction of the report on the agrarian problem of the province of Cordoba of $1919^{24}$. Eza makes a direct contribution to this in the form of the 'Questionnaire drafted to obtain employer and worker information by the Hon. Mr. Vizconde de Eza, President of the Institute of Social Reforms and of the Commission sent to the

17. Eza, Conservación y creación de las pequeñas explotaciones agrícolas, 1911, 25.

18. Ibid., 36.

19. O. Elorrieta, Ordenación económica de la producción agraria (Madrid: Inst. Forestal de Investigaciones y Experiencias, 1941).

20. Vizconde de Eza, La exhumación de los señoríos (Madrid: Imp. y Enc. Suc. M. Minuesa de los Ríos, 1932).

21. Malefakis. Reforma agraria y revolución campesina en la España del siglo XX.

22. G. Amor, "La propiedad y la cuestión agraria," La Paz Social, 9(1907): 453-457.

23. J. Maurice, La reforma agraria en España en el siglo XX (1900-1936) (Madrid: Siglo XXI, 1975).

24. Información Información sobre el problema agrario en la provincia de Córdoba. (Madrid: Sobrinos de la Sucesora de M. Minuesa de los Ríos, 1919). 
province of Cordoba by the Royal Decree of January 14, 1911'. It includes 22 questions related to the origin of the conflict, the conditions of cultivation, the agrarian property, the days of work, the dismemberment of large properties, the subdivision of the property and the transformation into irrigation, the collective leases or agricultural credits ${ }^{25}$. The solution to this social-agrarian problem of the province of Cordoba is found in the expropriation and parceling of uncultivated lands and in the improvement of crops. Thus, the problem of the Cordovan field is a problem of colonization, by means of the constitution of family lots with an extension between 2 and 10 hectares, located in the ring of the population nuclei to facilitate access to the new agricultural exploitations ${ }^{26}$. The Central Board of Colonization and Internal Repopulation ${ }^{27}$ assume these recommendations. It is interesting to highlight the insistence to consider nuances in the agrarian problem, associated with the specific characteristics of the different municipalities or agrarian districts. This point of view can also be found in other recognized catholic-social contributions, such as that of Aznar ${ }^{28}$, who also stated that the social-agrarian problem is different between regions, and even within each region. Three major regions can be distinguished in this regard: (1) Galicia, where the cause of the crisis is in the 'foros', the 'caciquismo', and the loss of income and remarkable fragmentation of property; (2) in the two Castiles, the main problems would be: the agrarian agitators, the excessive parceling of the land for an intensive and technical cultivation and, finally, the forced unemployment of 'nomad workers' not attached to the land; (3) finally, in Andalusia and Extremadura the main problems would be: lack of education and agricultural capital, poor communication channels, absenteeism, concentration of land, indolence at work, the subsistence of the rural cacique.

After his visit to the province of Cordoba, Eza suggests two types of solutions ${ }^{29}$ : (1) immediate and transitory, based on changes in the contracting system and agreements between employers and workers; (2) fundamental and deferred, linked to the modification of the current property regime, covering as many families as possible: through the conversion of day laborers into small landowners by colonization by the State or by private individuals with the help of the State. In the year 1919, coinciding with the report on the situation in Cordoba, the Agricultural and Livestock Progress ${ }^{30}$, published an editorial entitled 'The Land Question', in which it remarked upon the regional and even provincial character of the agrarian question in Spain, suggesting the inadvisability of 'destroying, through general laws, an excellent agrarian regime of the almost totality of Spain because this does not exist in a few provinces ...

25. Ibid., 71-72.

26. Ibid.

27. Junta Central de Colonización y Repoblación Interior, Nota informativa de la colonización interior en España, que presenta al Congreso de la Asociación para el Progreso de las Ciencias (Coimbra, 1925) (Madrid: Imp. Helénica, 1925).

28. S. Aznar, El catolicismo social en España. Nuestro primer curso social (Zaragoza: Mariano Escar Tip., 1907), 7.

29. Vizconde de Eza, El problema agrario andaluz (Madrid: Imp. Bernardo Rodríguez, 1919).

30. Cuestión "La cuestión de la tierra," El Progreso Agrícola y Pecuario, 30 de junio, 1113 (1919): 333-334. 
31. In the same way that sustains that the reform should be inspired in an eminently practical sense.

Eza's position anticipates some more recent historiographical trends, by not participating in the traditional view of the 'latifundio' as an inefficient exploitation $^{32}$. For Eza, as for some agrarian historians, many 'latifundistas' carried out an adequate form of exploitation in relation to the physical environment, climatology and soils. The large property was well adapted to the environment. Social conflict was linked to political changes and changes in labor relations and in the organization of work due to changes in the product market. According to Carmona and Simpson ${ }^{33}$, concentration and dispersion were the two sides of the agrarian problem, with a regional dimension, as Eza had already pointed out, throughout the first third of the 20th century. For Eza, as others suggested later, large estates were not a problem in themselves. The problem is not the size of the property but an appropriate management of the conditions of the physical environment. Here, according to Eza the geographical environment imposes conditions on the individual, who through the business management of resources can improve the environmental conditions for their activity and way of life. In fact, Eza uses and develops the work of the geographer Dantin Cereceda who established a regional physical dimension of Spain ${ }^{34}$, in which he stated that the agriculture of a country depends on the climate and soil or that 'agriculture is but the most faithful geographical expression ${ }^{35}$.

\section{The Debate about the Value of the Individual}

There are three dimensions to the debate about the individual, based on the catholic-social ideology of the time: the union of the individual with the right to individual property; the moral difference between the rural individual and the urban individual; and, the limitation of the intervention of the State to favor the social and economic capacity of each individual. Property, for Eza, has an eminently individual, but also a collective character when inserted in a certain social environment ${ }^{36}$. One of the tasks of agricultural cooperation is the harmonization of collective life and individual initiative ${ }^{37}$. For Eza, the agrarian

31. Ibid., 334.

32. J. Carmona, and J. Simpson, El laberinto de la agricultura española: instituciones, contratos y organización entre 1850 y 1936 (Zaragoza: Prensas Universitarias de Zaragoza, 2003).

33. Ibid.

34. J. Dantín Cereceda, Ensayo acerca de las regiones naturales de España (Madrid: J. Cosano, 1922); J. Dantín Cereceda, Concepto presente de la región natural en geografía (Madrid: Hernando, 1925).

35. Dantín Cereceda, Ensayo acerca de las regiones naturales de España, 1922, 41.

36. Vizconde de Eza, La reforma agraria en España (Madrid: Imp. Suc. Minuesa de los Ríos, 1931).

37. Vizconde de Eza, La cooperación agrícola: su exención fiscal. Informe presentado a la Agrupación Parlamentaria Agrícola (Madrid: Imp. Asilo de huérfanos, 1904). 
problem has three vertices: the State, the society and the individual ${ }^{38}$. State intervention should be reduced to hydraulic works, land consolidation and internal colonization. An intrinsic characteristic of field workers is absolute freedom of action and initiative, in contrast to the highly regimented factory population ${ }^{39}$. The institutions should only improve agricultural production by affecting the economic condition of the farmer, which will cause a moral elevation ${ }^{40}$. The State must contribute to the full development of the rural individual. Eza considered it necessary to take advantage of the good qualities of the peasant spirit and place them at the service of agricultural progress ${ }^{41}$, even by encouraging them to return to the agrarian field: 'the rural exodus taking place today must be replaced by an urban exodus ${ }^{41}$. This point of view was also taken by other social Catholics who talked about reintegration into the countryside $^{42}$, by dignifying the profession of the farmer and valuing the individual (rural) ${ }^{43}$, once the negative effects of the migration from the countryside to the city had begun to be observed ${ }^{44}$.

He despised the division between farmer (field) and worker (city), and during his period as Mayor of Madrid announced that 'the world is big enough for everyone to fit in $\mathrm{it}^{45}$. This differentiation between the agrarian and rural individual frequently appears in Eza's trajectory. In his agrarian program, he indicates: 'the agrarian community (...) has much greater social and economic stability than the urban-industrial and commercial community ....46. Agrarian life is linked to a set of unique moral virtues. The peasant observes that the other social classes do not have the least feeling of gratitude towards him, and even less empathy for the sacrifices that rural life represents; a life of self-denial and suffering ... ${ }^{47}$. In any case, this idealization of the rural life and family (as opposed to the city) is common among social Catholics during the first third of the twentieth century. Pedro Ricaldone in 1903 indicates: 'in the countryside on the contrary (to the city) marriages are proportionally more numerous and births more abundant: diseases are scarce and mortality is lower. All the elements offered by our physiological and moral lives have a sweet attraction and poetic charm in the rural area. There, unforgettable patriarchal traditions of respect reign and each home is an idyll of pure and Christian love. Living is

38. Vizconde de Eza, El problema agrario en España (Madrid: Imp. Bernardo Rodríguez, 1915).

39 Eza, El riesgo profesional en la agricultura, 1906.

40. Vizconde de Eza, "Prologue -July 1905-“. La cooperación agrícola en el extranjero, edited by Rivas Moreno, F. (Madrid: Ambrosio Pérez y Cía., 1907): 7-23.

41. Eza, "Prologo -Julio de 1905," in La cooperación agrícola en el extranjero, ed. F. Rivas Moreno (Madrid: Ambrosio Pérez y Cía., 1907), 6.

42. J. Mallart, La elevación moral y material del campesino (Madrid: Gráfica Mundial, 1933).

43. L. Leal, "Factores jurídicos y sociales del problema agrario en España," in Discursos y artículos de León Leal Ramos. Temas sociales, jurídicos y religiosos (Cáceres, Anaya, 1959, original 1934), 195-208.

44. J. Rodríguez Labandeira, El trabajo rural en España, 1876-1936 (Madrid, Anthropos, Ministry of Agriculture, fishing and food, 1991).

45. Eza, La tahona reguladora, 1914, 18.

46. Eza, Agrarismo (Madrid: C. Bermejo Imp, 1936), 34.

47. Ibid., 40-41. 
more hygienic, the body is strengthened, and the soul rises to sweet expansions. The needs are more limited and humble; the spirit of saving becomes a habit and almost derives in sweet need, the bonds of family are narrowed and confirmed, and the spirit of religiosity is always deeply rooted in those peaceful masses, whose calloused hands and bronzed complexions give us a great idea of the nobility of the work of Christian resignation' ${ }^{48}$.

In general, Eza is in favor of free commercial contracting and opposes the system of fees ${ }^{49}$. He criticizes excessive regulation in agriculture and praises a certain economic freedom of the farmer ${ }^{50}$, where he can show his individual capabilities. In any case, this criticism of the system of rates and competition through technical progress is conditioned by the characteristics of agriculture, especially in areas of central Spain: 'but agriculture must be the basis of any tariff policy in Spain, and these agricultural products must continue to maintain our exports and constitute the strongest support of our foreign trade. Hence, it can be affirmed that, although Spain must be to some extent protectionist, for the good of this same agriculture in its internal branches of insurance in wheat and cattle for national consumption, it must harmonize that protection with prudence, the only way that we do not kill our export reducing Spanish life to the rickets of favoring some manufacturing branch ${ }^{51}$.

\section{The Family and Small Farm}

For Eza 'agriculture plays a key role in the international organization of work $^{152}$. At the same time, he suggests that 'the tendency at present to increase and consolidate the rural class composed of small landowners and cultivators, is universal ${ }^{53}$. The Viscount is favorable to the establishment of a large rural class that relies on the possession and enjoyment of enough rustic property to feed a peasant family ${ }^{54}$. He refers to 'the social force that in itself contains the individual property, directing all efforts towards achievement of the ideal, which consists in making owners of all men ${ }^{55}$. Rural life rests on the basis of the peasant family ${ }^{56}$. From all perspectives, these opinions reveal that the ideal worker is the small owner; owner of his own means of production, his house,

48. P. Ricaldone, Los labradores, la agricultura y la cuestión social (Sevilla: Biblioteca agraria solariana, 1903), 89.

49. Vizconde de Eza, El problema de los trigos: informe de la Asociación de Agricultores de España (Madrid: M. Minuesa, 1916).

50. Vizconde de Eza, Agrarismo (Madrid: C. Bermejo Imp.: 1936).

51. Vizconde de Eza, El problema económico en España (Madrid: Sobrinos de la Suc. De M. Minuesa de los Ríos, 1919), 18.

52. Vizconde de Eza, La agricultura en la organización internacional del trabajo (Madrid: Sobrinos de la Suc. De M. Minuesa de los Ríos, 1920), 6.

53. Eza, Conservación y creación de las pequeñas explotaciones agrícolas, 1911, 5.

54. Ibid., 8 .

55. Ibid., 8.

56. Ibid., 40. 
his garden and his animals ${ }^{57}$. In addition, the installation of families in small properties limited emigration to the cities ${ }^{58}$. At this point, Eza coincides with the program of social Catholicism of the time: the idealization of the small agricultural owner ${ }^{59}$. As Aznar observed ${ }^{60}$, the effectiveness of work is different when you work for yourself than when you work to get a salary.

According to Gongora Echenique ${ }^{60}$, Eza distinguished three types of rural improvements: better farming, better business, better living. The first consisted in teaching the farmer modern methods of cultivation, the second in facilitating the association and transportation for his business and, finally, the third corresponded to educational, social and intellectual improvements of the (farmer) citizen. These improvements were aimed not only at increasing the rural population but also improving their location in the space and their living conditions ${ }^{61}$.

In his later writings, from during the Second Republic, he insists on basing agrarian reform on a small property and the development of a rural petty bourgeoisie: 'Where there is a rural petty bourgeoisie, this is shown as an element of strength and stability. The multiplication of these peasant proprietors can contribute to containing the depopulation of the countryside, which is one of the most glaring facts of contemporary evolution ${ }^{62}$. Thus, cultivation of smaller areas must be encouraged, because they employ more labor than large ones thus stopping rural depopulation. The agrarian economy must be based on family farming. Deep agrarian reform should consist in establish small individual owners ${ }^{63}$. The development of small farms must be based mainly on credit. Encouragement of entrepreneurial responsibility of the small farmer and the prevention of activities of agrarian reform and colonization, imposed especially from $1926^{64}$ with paralysis of the colonies policy of 1907, was excessively burdensome for the State. In Eza's thinking there were three parameters in the profitability of the company (agrarian) ${ }^{65}:$ (a) qualitative, based on the productive elements (nature, capital and work), which concur in the productive process; (b) the quantitative proportion of these elements in the agrarian enterprise; (c) the absolute magnitude of these elements.

Land reform must be implemented according to a plan that sets the goals and the most propitious means to achieve them, and establishes the precise

57. Eza, El riesgo profesional en la agricultura, 1906; Eza, "Requisitos indispensables para la difusión de la propiedad privada," Boletín de la Junta Central de Colonización y Repoblación Interior, 20, 4 trimestre (1923): 3-27.

58. M. Góngora, El problema de la tierra: opiniones e iniciativas de los señores Alba, Argente, Aznar, Bernaldo de Quirós... (Madrid: Góngora, 1922).

59. Malefakis, Reforma agraria y revolución campesina en la España del siglo XX.

60. Góngora, El problema de la tierra: opiniones e iniciativas de los señores Alba, Argente, Aznar, Bernaldo de Quirós..., 33.

61. F. Soler Pérez, Población rural (Madrid: V. Rico Imp., 1919).

62. Eza, De mis carpetas II. La reforma agraria y el crédito (Madrid: Imp. Sobrinos M. Minuesa de los Ríos, 1933), 49.

63. Ibid., 98.

64. Malefakis, Reforma agraria y revolución campesina en la España del siglo XX; Rodríguez Labandeira, El trabajo rural en España, 1876-1936, 1991.

65. Eza, La reforma agraria en España. 
human type to carry out transformation of the countryside. It should always remain within the framework of the law ${ }^{66}$ and should be governed by respect for individual assets. However, the notion of family agricultural heritage was changed by many other agrarists of the period ${ }^{67}$, based on the agrarian modernization process ${ }^{68}$ with different regional and international nuances ${ }^{69}$.

\section{Eza and the Agrarian Colonization}

Coinciding with the promulgation of the law of agricultural colonies of 1907, the Vizconde of Eza was the General Director of Agriculture. As indicated in 1911 the colonies would be the real 'agro-social laboratories ${ }^{70}$. He often set an example of some colonies generated by the Board of Colonization and Internal Repopulation in his more general writings on agrarian policy. His problem was to obtain land for colonization, respecting individual and private property, in addition to problems of the agrarian technique linked to colonization based on family lots ${ }^{71}$. In this sense, Eza suggests that The working class of the field, in all the countries of the world, (is) superior in number and more in need of shelter, in terms of their economic and social situation $^{72}$. Interior colonization founded on the 'family property' was intended to be an intermediate step between the smallholding and the large estate ${ }^{73}$. This social foundation of colonization had already been recognized in the IX International Congress of Agriculture ${ }^{74}$, in which considerable importance was given to the creation of small farms and to the means to attract the owners to the countryside and prevent the emigration of agricultural workers ${ }^{75}$. In this way, we should not criticize Eza because of the limited scope of the colonization policy ${ }^{76}$, given that perhaps this was not a clear purpose of the

66. Eza, De mis carpetas II. La reforma agraria y el crédito.

67. J.Algarra, Colonización de España. Exposición de Economía Social. Barcelona, 1911 (Barcelona: Imprenta y librería de Monserrat, 1911).

68. R. Moreno, "El paro forzoso en la agricultura," La Paz Social, 51(1911): 230-248.

69. P. Caziot, La terre à la familia paysanne: une soloution du probleme agraire (Paris: Payot, 1919).

70. Eza, Conservación y creación de las pequeñas explotaciones agrícolas, 22.

71. Junta Central de Colonización y Repoblación Interior, Estudios e informes relativos a la colonización agrícola de la zona de protectorado de España en Marruecos (Madrid, Imp. Helénica, 1923).

72. Eza, La agricultura en la organización internacional del trabajo, 7.

73. C. De Castro, La revolución desde arriba. Ensayo sobre la reforma agraria y la colonización interior (Madrid:Sociedad General Española de Librerías, 1921).

74. Congreso IX Congreso internacional de Agricultura: celebrado en Madrid del 1 al 7 de mayo de 1911 (Madrid: Tip. J.R. Martín, 1912).

75. S. Aznar, Despoblación y colonización (Barcelona: Labor, 1930).

76. F.J. Monclus, and J.L. Oyon, "De la colonización interior a la colonización integral (1900-1936). Génesis y destino de una reforma agraria técnica," in Historia agraria de la España contemporánea. 3. El fin de la agricultura tradicional (1900-1960), ed. R., Garrabou, C. Barciela and J.I.Jiménez (Barcelona: Crítica, 1986); R. Robledo, "Política y reforma agraria: de la Restauración a la II República (1868/74-1939)," in Reformas y políticas agrarias en la historia de España, ed. A. García Sanz and J. Sanz Fernández, (Madrid: MAPA, 1996): 247350 . 
ideologists of the agrarian colonization of $1907^{77}$. Instead, we can regard it as the development of singular colonies that served as an example of how to establish lots or agrarian family patrimonies in different parts of the Spanish geography, with a differentiated natural and socioeconomic environment. These would constitute regional examples of agrarian colonization ${ }^{78}$. This qualitative interpretation of the colonization of 1907 seems more appropriate to the ends, even personal ones, of Eza himself. He claimed that it was better to have few settlers, provided these were successful ${ }^{79}$. But, it is Eza himself, recognizing the depth of the social problem in Andalusia, who states in 1919 that not even significantly extending the colonized area would end the social conflict ${ }^{80}$. Here, also, Eza recognizes a specific social dimension to the agrarian problem, which differentiates it from other catholic-social ones. The formula, in any case, was too 'expensive' for a public budget deficit.

Eza's position in relation to colonization was critical, based on the high costs of internal colonization for the State, arising from its intervention in depopulated and uncultivated areas ${ }^{81}$. The State should only give the land of labor and the settler must do everything else ${ }^{82}$. Internal migration had to be fought in a way that was compatible with the freedom of the individual, not only by colonization, which was too onerous for the State ${ }^{83}$. Some agrarists, like Cascon (Agronomist, director of the Agricultural Farm of Palencia and since 1916 member of the Agronomic Advisory Board) ${ }^{84}$, denounced Eza as a 'trumpeter', for his involvement in the model of colonization. The only interest of the large landowners, according to reformist critics of Eza, was to extract the highest income and preserve their rights. The property must be founded on work. The number of land owners had to be increased, but without an increase in the deficit of the public treasury ${ }^{85}$. Implicitly, the welfare state was criticized -even within the social Catholics- ${ }^{86}$. This point of view was finally imposed in 1926, as previously indicated, and in certain aspects would culminate in the technical arguments of republican agrarian reform. In Eza's own thinking, the solution to agrarian credit can be regarded progressively, so that each farmer

77. Maurice, La reforma agraria en España en el siglo XX (1900-1936), 1975.

78. A. Paniagua, Repercusiones sociodemográficas de la policía de colonización durante el siglo XIX y primer tercio del XX (Madrid: MAPA, 1992)

79. Eza, "La política social en España," Boletín de la Junta Central de Colonización y Repoblación Interior, 24, 4 trimestre(1924): 6-14.

80. Eza, "Importancia de la colonización en España," Boletín de la Junta Central de Colonización y Repoblación Interior, primer trimestre (1919): 6-23.

81. Junta Central de Colonización y Repoblación Interior. Las colonias agrícolas. Folleto divulgador del proyecto, organización, desarrollo y estado actual de la colonia agrícola de 'Els Plans' (Alcoy) al quinto año de su instalación (Madrid: Imp. Alemana, 1916)

82. J. Cascon, La cuestión agraria: España puede colonizarse. Una réplica a los Sres. Zulueta y Vizconde de Eza (Madrid: Mario Auguiano, 1916).

83. F. Soler Pérez, La crisis rural (Madrid: Fco. Beltrán, 1918).

84. Cascón, La cuestión agraria: España puede colonizarse. Una réplica a los Sres. Zulueta y Vizconde de Eza, 1916.

85. F. Soler Pérez, Función social de la propiedad del suelo (Madrid: Est. Tip. Jaime Rates, 1919).

86. F. Rivas, Los progresos del campo y la cooperación (Madrid: Hernando, 1926). 
could develop his individual qualities in the management of his family property.

Eza's critics, who supported a technical reform, may have been right, but the technical foundations in the subsequent intervention, for example, of the Institute of Agrarian Reform when establishing communities of peasants in the Second Republic are also true. The prosecution of Eza arises from the social limitations of the state action for the solution of an agrarian problem, that in a regionalized way, Eza recognized. The qualitative vision of the colonization of the first quarter of the twentieth century intended to be an effective way to: '(1) find out the most conducive means to obtain the highest yield of profits, and, consequently, an increase in the national wealth, of each part of the territory of which a given town is in possession (...) (2), to discover the most feasible way for each nation to have the largest possible population nucleus fed by their work, educated in their profession and trained every day to aspire to rise to the sphere of progress and civilization ${ }^{87}$. The colonies, under this previously described qualitative vision, did not want to be more than a living expression that contributed to the national synthesis that Eza proclaimed in the regional studies. In any case, Eza became aware of the limitations of respect for individual property adapted to the environment and the depth of the social problem in some areas analyzed. Eza saw this contradiction more implicitly than explicitly. But, it will always be in favor of an orderly and measured intervention of the State in the agrarian structure. Maintaining the rural population and raising its material standard of living and moral condition, together with a situation of seasonal unemployment and a structure of property, which in physical-agronomic terms would be appropriate, is another of the contradictions and problems with facing Eza and, in general, the catholic-social ideology ${ }^{88}$.

\section{The Agrarian Program}

In general terms, Eza recognizes that agricultural progress is 'palmary' in Spain $^{89}$. An opinion that reflects wise judgments about the agriculture of the time, as was revealed later ${ }^{90}$. The agrarian problem in Spain is not unique and has different modalities and nuances, even at municipal or regional scales ${ }^{91}$. As Eza pointed out in 1931: 'The diversity of the countryside is such, not only in counties and provinces, but even in each municipal area, which cannot be

87. Eza, Conservación y creación de las pequeñas explotaciones agrícolas, 23.

88. Aznar, ¿Decadencia, senectud o crisis de crecimiento? (Madrid: Ruiz, 1930), 73 and sucesive.

89. Eza, La tahona reguladora, 18.

90. J.I. Jiménez Blanco, "Introducción," in Historia agraria de la España contemporánea. 3. El fin de la agricultura tradicional (1900-1960), ed. R. Garrabou, C. Barciela, and J.I. Jiménez (Barcelona: Crítica, 1986): 9-141.

91. Junta Central de Colonización y Repoblación Interior, Nota informativa de la colonización interior en España, que presenta al Congreso de la Asociación para el Progreso de las Ciencias (Coimbra, 1925). 
generalized when it comes to social structure and economic organization ... ${ }^{92}$. The main problems are economic, based on: profit and social returns and feeding the largest possible number of people by their own labor ${ }^{93}$. Eza leaves profitable large estates outside all reform ${ }^{94}$, faced with the social fact that some farms do not yield what they should in agronomical terms. Society is empowered by the natural law to reintegrate into its domain so that it can provide greater wealth. Gongora's ${ }^{95}$ interpretation of Eza's ideology includes recognition of 'latifundio' or large property, provided that its use is consistent with its agronomic characteristics and the settlement system concentrated in distant settlements between them. This point of view was questioned decades later by Martínez Alier in his study on the Stability of latifundio.

The convenience or not of the small or large farm will depend on various factors, especially the availability of land. There will be areas where the large property is better and areas where the small property will be more suitable ${ }^{96}$. For Eza, one of the objects of the agrarian reform was its geographic delimitation. The 'latifundio' is only favorable in Andalusia, La Mancha and Extremadura. But, the reform strategy in the 'latifundios' should consist of the improvement of dry-land crops that are deficiently exploited in a 'convenient parceling ${ }^{197}$, of around $10 \%$ of the surface of each 'latifundio'. For these conclusions, he combines the social laboratory -even on parcels on his own land - and a remarkable knowledge of international literature. The large estate is not necessarily deplorable and accepts a regional adaptation in the extension of the smallholding and the 'latifundio'. Consequently, the task of colonization and reform must follow regional guidelines. This position has been interpreted later as shoring up the stability of the 'latifundio' in a stage of rural change, with a modification in the wage labor system by another employee with incentives without real economic independence, which would constitute sharecropping. Also, in this sense Martínez Alier - by contrast to Eza's claims decades before pointed out that ecology is irrelevant in the stability of the 'latifundio' as the very type of settlement ${ }^{98}$.

For Eza, agrarian reform 'must consist in establishing on the farms (...), a farmer endowed with strong production elements and intense social collaborations in order to achieve their economic improvement and the citizens' elevation ${ }^{\prime 99}$. In his later work Agrarismo ${ }^{100}$, it defines its agrarian program based on the need for field reforms, associated with the following bases: (1) the prosperity of agriculture; (2) the broader distribution of capital among small

92. Eza, La reforma agraria en España, 18.

93. Eza, Conservación y creación de las pequeñas explotaciones agrícolas, 23.

94. Eza, "Importancia de la colonización en España," Boletín de la Junta Central de Colonización y Repoblación Interior (1919): 6-23.

95. J. Martínez Alier, Labourers and landowners in southern Spain (London: Allen and Unwin, 1971).

96. Eza, La reforma agraria en España.

97. J.J. Castillo, Propietarios muy pobres. Sobre la subordinación política del pequeño campesino (Madrid: MAPA., 1979)

98. Martínez Alier, Labourers and landowners in southern Spain, 27.

99. Eza, La reforma agraria en España, 5.

100. Eza, Agrarismo. 
and medium-sized farms; (3) the collaboration of all types of citizens. Agrarianism is identified with individualism and is opposed to collectivism. Eza himself defines agrarianism as: 'the determination of the agronomic circumstances that concur in our territory, as well as of the indispensable elements for the convenient production use of those by coordinating the latter in three orders of technical improvement, social interdependence and legal norms that submit and adopt them to the organic structure that responds to the maximum performance of the economic and educative energies ... '. The solution to the agrarian problem lay in political stability -one of the characteristics of agrarian colonization programs- and a social, economic and legal organization adapted to obtain the highest yield on the land -a regionalization of the reform policies associated with the agronomic characteristics-. Agrarianism 'is a method to carve out a life' which privileges enough property for the existence of a family. These judgments of Eza are a constant in his work. Already, The agrarian problem of Spain ${ }^{101}$ published in another national and international sociopolitical context, in similar terms, stated that the agrarian problem is the determination of the agronomic circumstances that occur in our territory, as well as of the indispensable elements for the convenient production utilization of these through the coordination of three dimensions: technical improvement, social interdependence and legal changes $^{102}$.

One of the characteristics of Eza was the combination of the micro social laboratory, taking as an example the parceling and colonization activities -and even his private plots on his farms- and the international examples. This led him to write some works on the comparative results of agrarian reform in Europe $^{103}$, from which it can be concluded that agricultural property has typical aspects in each country. For this reason, in some countries measures of concentration or division of land had been put in place, with the intervention of the State, while in others the land was disintegrated, distributed and concentrated by the set of economic laws. The socio-economic context surrounding agriculture in each country is also different and has a significant impact on the analysis of rural life and State policies.

\section{Conclusion}

As indicated above, Eza is a figure of multiple profiles and interests, among which those of social-agrarian are particularly noteworthy. His agrarian concern reflects, to a certain extent, his status as a great social owner, as his own workers saw him. Not only was he a theoretician, he also carried out social-agrarian experiments, even with parceling on his own farms. The

101. Eza, El problema agrario en España.

102. Eza, El problema agrario en España, 11.

103. Eza, Resultados de la reforma agraria en Europa (Madrid: Asociación Española para el Progreso de las Ciencias, 1929); Eza, La tierra y la política en Inglaterra (Madrid: Imp. y Enc. Suc. M. Minuesa de los Ríos, 1932). 
distribution of his properties between Soria and Córdoba undoubtedly influenced many of his agrarian judgments.

The analysis of Eza's work allows us to review some points of view relating to a period, the first third of the 20th century, which has been characterized by social-agrarian history as a time of little movement in the agrarian structure that nourished the emergence of the agrarian reform during the Second Republic ${ }^{104}$. It is even known as a period of transition stage where actions or inactions have as a final result the agrarian reform of the Second Republic ${ }^{105}$. The southern perspective of the agrarian question has traditionally obscured facts accepted today such as the increase in agricultural productivity and capitalization, the increase in cultivated area or the decrease (in absolute and relative terms) in the rural and agrarian population ${ }^{106}$. All these facts and tendencies were already incorporated by Eza in his thoughts and writings of social-agrarian policy. It could even be suggested that, because of his social tendency, Eza was one of the social Catholics most prone to the intervention (direct) of the State. He recognized a remarkable southern social dimension of the agrarian problem, whose solution was not exclusively subject to technical and credit improvements.

Eza's ideology was novel in some historiographical aspects. In his analysis of the 'latifundio' he proposed that the great property was not negative in itself, provided that it was adapted to the physical environment and properly managed. The large properties in Extremadura and Andalusia responded, to a large extent, to the restrictions of the physical environment and, secondarily, to the historical process of repopulation. Parceling and colonization would only be beneficial in a limited part of the latifundio, the part closest to the population.

For Eza, the problem lies in the structure of the property. Small and large properties are two aspects of the same problem. The solution in one case is concentration and in the other parceling, through agrarian colonization based on the family patrimony. Consequently, the agrarian policy must be regionalized. This is another feature of Eza's agrarian ideology: recognition of the diversity of problems and agrarian issues in Spain and the multiplicity of solutions. Eza proposed the region as an appropriate geographical unit in which to approach rural problems and agrarian solutions. Here, Eza refers to expositions developed by some historians: the regional specialization of agriculture and the existence of diverse agrarian questions and solutions, to problems with different $\operatorname{roots}^{107}$.

Above all, Eza has a dual vision of space and society that characterized rural life in the twentieth century ${ }^{108}$. This dual agrarian ideology of the Viscount is embodied in diverse relationships: (1) field-city, (2) localityglobality, (3) small-great property, (4) individual-State, which correspond to some of the fundamental and permanent binary associations in his agrarian

104. Malefekis, Reforma agraria y revolución campesina en la España del siglo XX. Rodríguez Labandeira, El trabajo rural en España, 1876-1936, 199.

105. Maurice, La reforma agraria en España en el siglo XX (1900-1936).

106. Jiménez Blanco, "Introducción".

107. Ibid.

108. J. Sánchez Jiménez, La vida rural en la España del Siglo XX Barcelona: Planeta, 1975. 
ideology. (1) The countryside and the city appear as two differentiated social entities: there were moral values and a type of life typical of the countryside and others characteristic of the city. This duality has a moral-social rather than a spatial foundation and overshadows a more territorial duality: the rural-urban one, which hardly appears in his ideology. (2) The second duality is associated with analysis of the agrarian question that is often based on social-agrarian laboratories in farms or localities and the study of agrarian issues at an international level, which Eza combines masterfully in his analyses. This shows how the local agrarian social processes had an international explanatory context. (3) The binary difference between small and large properties encloses the regional complexity of the agrarian question in Eza's agrarian ideology. In both cases, the solution was an adequate management in relation to environmental conditions and internal colonization through the constitution of family agrarian patrimonies. In any case, gradually Eza opts for a concentration of the properties and a certain consideration for the 'latifundio'. (4) The fourth duality that characterizes Eza's ideology connects with the differentiated role of the individual (creator) and the State (regulator). Allowing for the agrarian individual to develop capacities in the management of his exploitation, in a certain social framework, is a characteristic of Eza's ideology. In this way, inequality between individuals is not necessarily regarded as negative -one of the characteristics of social Catholicism in Spain ${ }^{109}$, but rather as being the result of the unequal natural conditions of man and the generation of dependency relationships. The State must configure a regulatory framework that guarantees the development of individual capacities, especially the individual right to property (agrarian). The State, above all, must have a subsidiary nature.

All these binary axes of Eza's ideology remain constant throughout his work despite the remarkable historical ups and downs that occur during the first 40 years of the twentieth century. They also grant a remarkable social and geographical character to their thinking: regional differentiation, the field-city relationship, the geographical value of the individual (rural) -with a somewhat relational view of the rural space-, the influence of transport and the disposition of the settlements. These are some of the topics of notorious geographic content. Eza's own way of carrying out agrarian research today would have a lot of geo-ethnography.

\section{Bibliography}

Algarra, J. Colonización de España. Exposición de Economía Social. Barcelona, 1911. Barcelona: Imprenta y librería de Monserrat, 1911.

Amor, G. "La propiedad y la cuestión agraria." La Paz Social, 9(1907): 453-457.

Aznar, S. Despoblación y colonización. Barcelona: Labor, 1930.

Aznar, S. El catolicismo social en España. Nuestro primer curso social. Zaragoza: Mariano Escar Tip., 1907.

109. Aznar, Despoblación y colonización. 
Calama, A. "El Vizconde de Eza Don Luis Marichalar y Monreal (1873-1945). Político e intelectual, diputado a Cortes por Soria de 1899 a 1923, Alcalde de Madrid (1913-1914)". Torre de los Lujanes. Boletín de la Real Sociedad Económica Matritense de Amigos del País, 61(2007): 71-115.

Campo, F. "El vizconde de Eza y la cooperación." Estudios Cooperativos, 16(1968): $27-40$.

Cascon, J. La cuestión agraria: España puede colonizarse. Una réplica a los Sres. Zulueta y Vizconde de Eza. Madrid: Mario Auguiano, 1916.

Carmona, J., and Simpson, J. El laberinto de la agricultura española: instituciones, contratos y organización entre 1850 y 1936. Zaragoza: Prensas Universitarias de Zaragoza, 2003.

Castillo, J.J. Propietarios muy pobres. Sobre la subordinación política del pequeño campesino. Madrid: MAPA, 1979.

Caziot, P. La terre à la familia paysanne: une soloution du probleme agraire. Paris: Payot, 1919.

Congreso IX Congreso internacional de Agricultura: celebrado en Madrid del 1 al 7 de mayo de 1911. Madrid: Tip. J.R. Martín, 1912.

Cuenca Toribio, J.M. Catolicismo social y político en la España contemporánea (1870-2000). Madrid: Unión Editorial, 2003.

Dantín Cereceda, J. Ensayo acerca de las regiones naturales de España. Madrid: J. Cosano, 1922.

Dantín Cereceda, J. Concepto presente de la región natural en geografía. Madrid: Hernando, 1925.

De Castro, C. La revolución desde arriba. Ensayo sobre la reforma agraria y la colonización interior. Madrid: Sociedad General Española de Librerías, 1921.

Elorrieta, O. Ordenación económica de la producción agraria. Madrid: Inst. Forestal de Investigaciones y Experiencias, 1941.

Eza, Vizconde de. La cooperación agrícola: su exención fiscal. Informe presentado a la Agrupación Parlamentaria Agrícola. Madrid: Imp. Asilo de huérfanos, 1904.

Eza, Vizconde de. "Prólogo -Julio de 1905." In La cooperación agrícola en el extranjero, edited by F. Rivas Moreno, 7-23. Madrid: Ambrosio Pérez y Cía., 1907.

Eza, Vizconde de. El riesgo profesional en la agricultura. Madrid: Suc. M. Minuesa de los Ríos, 1906.

Eza, Vizconde de. Conservación y creación de las pequeñas explotaciones agrícolas. Madrid: Bernardo Rodríguez, 1911.

Eza, Vizconde de. La tahona reguladora. Madrid: Sucesora de M. Minuesa de los Rios, 1914.

Eza, Vizconde de. El problema agrario en España. Madrid: Imp. Bernardo Rodríguez 1915.

Eza, Vizconde de. El problema de los trigos: informe de la Asociación de Agricultores de España. Madrid: M. Minuesa, 1916.

Eza, Vizconde de. El problema agrario andaluz. Madrid: Imp. Bernardo Rodríguez, 1919.

Eza, Vizconde de. "Importancia de la colonización en España." Boletín de la Junta Central de Colonización y Repoblación Interior, primer trimestre (1919): 6-23.

Eza, Vizconde de. "Requisitos indispensables para la difusión de la propiedad privada." Boletín de la Junta Central de Colonización y Repoblación Interior, 20, 4 trimestre (1923): 3-27.

Eza, Vizconde de. La agricultura en la organización internacional del trabajo. Madrid: Sobrinos de la Suc. De M. Minuesa de los Ríos, 1920. 
Eza, Vizconde de. "La política social en España." Boletín de la Junta Central de Colonización y Repoblación Interior, 24, 4 trimestre(1924): 6-14.

Eza, Vizconde de. El solar español: su fuerza social, económica y tributaria. Madrid: Ruiz hermanos, 1926.

Eza, Vizconde de. Resultados de la reforma agraria en Europa. Madrid: Asociación Española para el Progreso de las Ciencias, 1929.

Eza, Vizconde de. ¿Decadencia, senectud o crisis de crecimiento? Madrid: Ruiz, 1930.

Eza, Vizconde de. La reforma agraria en España. Madrid: Imp. Suc. Minuesa de los Ríos, 1931.

Eza, Vizconde de. La exhumación de los señoríos. Madrid: Imp. y Enc. Suc. M. Minuesa de los Ríos, 1932.

Eza, Vizconde de. La tierra y la política en Inglaterra. Madrid: Imp. y Enc. Suc. M. Minuesa de los Ríos, 1932.

Eza, Vizconde de. De mis carpetas II. La reforma agraria y el crédito. Madrid: Imp. Sobrinos M. Minuesa de los Ríos, 1933.

Eza, Vizconde de. Agrarismo. Madrid: C. Bermejo Imp.,1936.

Vizconde de Eza, El problema económico en España. Madrid: Sobrinos de la Suc. De M. Minuesa de los Ríos, 1919.

Góngora, M. El problema de la tierra: opiniones e iniciativas de los señores Alba, Argente, Aznar, Bernaldo de Quirós... Madrid: Góngora, 1922.

Información. Información sobre el problema agrario en la provincia de Córdoba. Madrid: Sobrinos de la Sucesora de M. Minuesa de los Ríos,1919.

Jiménez Blanco, J.I. "Introducción." In Historia agraria de la España contemporánea. 3. El fin de la agricultura tradicional (1900-1960), edited by R. Garrabou, C. Barciela, and J.I. Jiménez, 9-141. Barcelona: Crítica, 1986.

Junta Central de Colonización y Repoblación Interior. Las colonias agrícolas. Folleto divulgador del proyecto, organización, desarrollo y estado actual de la colonia agrícola de 'Els Plans' (Alcoy) al quinto año de su instalación. Madrid: Imp. Alemana, 1916.

Junta Central de Colonización y Repoblación Interior. Estudios e informes relativos a la colonización agrícola de la zona de protectorado de España en Marruecos. Madrid: Imp. Helénica, 1923.

Junta Central de Colonización y Repoblación Interior. Nota informativa de la colonización interior en España, que presenta al Congreso de la Asociación para el Progreso de las Ciencias (Coimbra, 1925). Madrid: Imp. Helénica, 1925.

Leal, L. "Factores jurídicos y sociales del problema agrario en España." In Discursos y artículos de León Leal Ramos. Temas sociales, jurídicos y religiosos, 195-208. Cáceres: Anaya, 1959, original of 1934.

Majuelo, E., and Pascual, A. Del catolicismo agrario al cooperativismo empresarial. Setenta y cinco años de la Federación de Cooperativas navarras, 1910-1985. Madrid: MAPA, 1991.

Malefakis, E. Reforma agraria y revolución campesina en la España del siglo XX. Barcelona: Ariel, 1982, original of 1970.

Mallart, J. La elevación moral y material del campesino. Madrid: Gráfica Mundial, 1933.

Martínez Alier, J. Labourers and landowners in southern Spain. London: Allen and Unwin, 1971.

Martínez González, S. La crisis de la agricultura. Sus causas y sus remedios. Salamanca: Imprenta Católica Salmanticense, 1893.

Martín Granizo, L. "Prologo." Antología de las obras del Excmo. Señor Vizconde de Eza, XI-XXXIX. Madrid: Escuela Social de Madrid, 1948. 
Maurice, J. La reforma agraria en España en el siglo XX (1900-1936). Madrid: Siglo XXI, 1975.

Molins, J.E. La crisis en España. Barcelona: Imp. Barcelonesa, 1904.

Monclus, F.J., and Oyon, J.L. "De la colonización interior a la colonización integral (1900-1936). Génesis y destino de una reforma agraria técnica." In Historia agraria de la España contemporánea. 3. El fin de la agricultura tradicional (1900-1960), edited by R., Garrabou, C. Barciela, J.I. Jiménez, 347-382. Barcelona, Crítica, 1986.

Moreno, R. "El paro forzoso en la agricultura." La Paz Social, 51(1911): 230-248.

Paniagua, A. Repercusiones sociodemográficas de la policía de colonización durante el siglo XIX y primer tercio del XX. Madrid: MAPA, 1992.

Ricaldone, P. Los labradores, la agricultura y la cuestión social. Sevilla: Biblioteca agraria solariana, 1903.

Rivas, F. Los progresos del campo y la cooperación. Madrid: Hernando, 1926.

Robledo, R. "Política y reforma agraria: de la Restauración a la II República (1868/741939)." Reformas y políticas agrarias en la historia de España, edited by A. García Sanz and J. Sanz Fernández, 247-350. Madrid: MAPA, 1996.

Rodríguez Labandeira, J. El trabajo rural en España, 1876-1936. Madrid: Anthropos, Ministry of Agriculture, fishing and Food, 1991.

Salcedo Ruiz, A. El socialismo del campo. Madrid: Imp. de los Huérfanos, 1894.

Sánchez Jiménez, J. La vida rural en la España del Siglo XX. Barcelona: Planeta, 1975.

Sangro, P. El Vizconde de Eza, gran señor social. Madrid: Ministerio de Trabajo, 1947.

Sevilla Guzmán, E. "Sobre el pensamiento social agrario en España." In Introducción a la sociología rural, edited by H. Newby, and E. Sevilla Guzmán. Madrid: Alianza Ed., 1983.

Soler Pérez, F. Población rural. Madrid: V. Rico Imp., 1919

Soler Pérez, F. La crisis rural. Madrid: Fco. Beltrán, 1918.

Soler Pérez, F. Función social de la propiedad del suelo. Madrid: Est. Tip. Jaime Rates, 1919. 
